\title{
AKTIVITAS ANTIOKSIDAN BEBERAPA TUMBUHAN OBAT KALIMANTAN TIMUR
}

\author{
Herman \\ Laboratorium Penelitian FARMAKATROPIS Fakultas Farmasi \\ Universitas Mulawarman, Samarinda, Kalimantan Timur \\ email: herman.farmasi@yahoo.com
}

\begin{abstract}
ABSTRAK
Telah dilakukan penelititan dengan judul analisis aktivitas antioksidan terhadap beberapa tumbuhan Kalimantan Timur yang dianggap sebagai obat. Penelitian ini bertujuan untuk mengidentifikasi golongan metabolit sekunder yang terkandung dalam ekstrak dan menguji aktivitas antioksidan. Metode yang digunakan untuk mengidentifikasi golongan metabiolit sekunder dilakukan dengan penambahan reagen kimia sedangkan untuk menetahui aktivitas antioksidan dengan metode peredaman radikal bebas DPPH terhadap ekstrak dan fraksi menggunakan spektofotometer UV-Visible dengan panjang gelombang $517 \mathrm{~nm}$. Hasil identifikasi golongan metabolit sekunder menunjukkan bahwa dari keempat jenis tumbuhan teridentifikasi mengandung golongan senyawa alkaloid, fenol, saponin, dan tanin serta aktivitas antioksidan dengan nilai $\mathrm{IC}_{50}$ dari ekstrak kasar maupun fraksi terbaiknya dibawah 100 ppm.
\end{abstract}

Kata Kunci: Antioksidan, Ageratum conyzoides L., Captosapelta Tomentosa V., Lepisanthes amoena, Acanthus ilicifolius L., DPPH

\begin{abstract}
Study with the title analysis of antioxidant activity against several plants east Kalimantan are considered as a drug. Study aims to identify the class of secondary metabolites contained in extracts and tested the antioxidant activity. The method used to identify the class of secondary metabolites made by the addition of chemical reagents and to determine the antioxidant activity by the DPPH free radical reduction method to extract and fractions using UV-Visible spectrophotometer with a wavelength of $517 \mathrm{~nm}$. The identification results showed that the class of secondary metabolites from plants identified four classes of compounds contains alkaloids, phenols, saponins and tannins and antioxidant activity with the best $I_{50}$ values of crude extract and fractions below 100 ppm.
\end{abstract}

Key Words: Antioxidant, Ageratum conyzoides L., Captosapelta Tomentosa V., Lepisanthes amoena, Acanthus ilicifolius L., DPPH

\section{PENDAHULUAN}

Pergeseran pola hidup masyarakat dari pola hidup tradisional menjadi pola hidup yang praktis dan instan, khususnya pada pemilihan makanan yang dikonsumsi, memiliki dampak negatif bagi kesehatan. Makanan cepat saji dengan pemanasan tinggi dan pembakaran merupakan pilihan dominan yang dapat memicu terbentuknya senyawa radikal (Poumorad, 2006). Beberapa studi epidemiologi menunjukkan 
bahwa peningkatan konsumsi antioksidan alami yang terdapat dalam buah, sayur mayur, dan tanaman serta produkproduknya mempunyai manfaat besar terhadap kesehatan yakni dapat mengurangi resiko terjadinya penyakit jantung koroner. Hal ini disebabkan karena adanya kandungan beberapa vitamin (A, C, $\mathrm{E}$, dan folat), serat, dan kandungan kimia lain seperti polifenol yang mampu menangkap radikal bebas (Gill, 2002).

Mengacu pada potensi tersebut, maka Kalimantan Timur memiliki potensi besar untuk menemukan senyawa antioksidan alami tersebut. Ratusan jenis spesies tanaman telah dipercaya berkhasiat untuk mengatasi berbagai macam penyakit. Penggunaannya secara turun temurun dan dilakukan dengan proses sederhana inilah yang dikenal dengan obat tradisional. Saat ini, penggunaan obat-obatan dari bahan alami semakin meningkat dan diperkirakan banyak yang mengandung senyawa antioksidan yang belum ditemukan.

Berdasarkan uraian di atas, dilakukan analisis untuk menentukan golongan senyawa metabolit sekunder serta uji aktivitas antioksidan dengan metode peredaman radikal 2,2-diphenyl-1picrylhidrazyl (DPPH) dari beberapa tumbuh-tumbuhan Kalimantan Timur yang dianggap sebagai obat.

\section{METODOLOGI PENELITIAN}

\section{a. Bahan Yang Diteliti}

Bahan yang diteliti dalam penelitian ini adalah tumbuhan yang diperoleh dari beberapa wilayah di Kalimantan Timur yang dianggap masyarakat sebagai obat antara lain: Tumbuhan Bandotan (Ageratum conyzoides L.), Tumbuhan Merung (Captosapelta Tomentosa Valeton K.), Tumbuhan Kokang (Lepisanthes amoena), dan Tumbuhan Daruju (Acanthus ilicifolius L.)

\section{b. Alat dan Bahan Penelitian}

Adapun alat yang digunakan dalam penelitian ini adalah seperangkat alat ekstraksi, rotary evaporator, magnetik stirer, timbangan digital, vorteks, desikator, mikropipet, spektrofotometer UV-Visibel, serta peralatan laboratorium kaca lainnya yang mendukung.

Sedangkan bahan yang digunakan dalam penelitian ini adalah pelarut metanol, etil asetat, n-heksana, n-butanol, 2,2-diphenyl1-picrylhidrazyl (DPPH), Vitamin C, pereaksi dragendorf, pereaksi mayer, serbuk magnesium, asam klorida, besi tiga klorida, dan aquadest.

\section{c. Pelaksanaan Penelitian}

\section{Penyiapan Sampel}

Penyiapan Sampel tumbuhan meliputi pengambilan dan pengolahan sampel. Pengambilan sampel tumbuhan dilakukan di beberapa daerah di Kalimantan Timur. Bahan atau sampel tumbuhan yang sudah diperoleh selanjutnya dipilih dan dibersihkan dengan air yang mengalir, selanjutnya dikeringkan tanpa sinar matahari. Sampel tumbuhan yang sudah kering selanjutnya dihaluskan atau dipotong siap dan untuk digunakan.

\section{Ekstraksi}

Sampel yang telah kering diekstraksi dengan pelarut metanol dengan metode maserasi. Hasil maserasi dipisahkan antara filtrat dan residunya dengan penyaringan dan selanjutnya diuapkan pelarutnya dengan menggunakan rotary evaporator sehingga diperoleh ekstrak kental. 
Selanjutnya ekstrak dikeringkan dengan menggunakan water batch dan desikator.

\section{Identifikasi Metabolit Sekunder}

Identifikasi golongan metabolit sekunder dilakukan dengan cara mereaksikan reagen kimia spesifik kepada beberapa golongan senyawa metabolit sekunder yang terkandung didalam ekstrak.

\section{Aktivitas Antioksidan}

Pengujian aktivitas antioksidan dilakukan dengan cara mengambil $3 \mathrm{~mL}$ ekstrak dari masing-masing konsentrasi uji, kemudian ditambahkan dengan $2 \mathrm{~mL}$ larutan DPPH 40 ppm. Selanjutnya Campuran larutan ini di homogenkan dengan menggunakan vorteks dan dibiarkan ditempat gelap pada suhu kamar selama 45 menit. Kemudian larutan diukur absorbansinya dengan menggunakan Spktrofotometer UV-Visible pada panjang gelombang maksimum (517 $\mathrm{nm}$ ) terhadap blanko (yang terdiri atas 3 $\mathrm{mL}$ ekstrak atau fraksi dan $2 \mathrm{~mL}$ etanol). Dilakukan juga pengukuran terhadap kontrol yang terdiri atas $2 \mathrm{~mL}$ DPPH 40 ppm dan $3 \mathrm{~mL}$ etanol. Dari hasil pengukuran absorbansi tersebut selanjutnya dihitung persen aktivitas antioksidan.

\section{HASIL DAN PEMBAHASAN}

Penelitian ini bertujuan untuk mengidentifikasi golongan metabolit sekunder dan menguji aktivitas antioksidan yang terkandung dalam ekstrak maupun fraksi dari beberapa tumbuhan di Kalimantan Timur yang dianggap masyarakat sebagai obat. Parameter metabolit sekunder yang diidentifikasi adalah golongan senyawa alkaloid, flavonoid, saponin, steroid/terpenoid, dan tanin, sedangkan aktivitas antioksidan ekstrak atau fraksi dilakukan peredaman terhadap diphenylpicrylhydrazyl (DPPH) dengan parameter nilai $\mathrm{IC}_{50}$.

\section{A. Identifikasi Golongan Metabolit Sekunder}

Golongan Senyawa metabolit sekunder merupakan produk alami yang sangat penting pada kelangsungan hidup suatu makhluk hidup. Sebagian besar tanaman penghasil senyawa metabolit sekunder memanfaatkan senyawa tersebut untuk mempertahankan diri dan berkompetisi dengan makhluk hidup lain di sekitarnya. Adapun kandungan golongan metabolit sekunder dari beberapa tumbuhan yang diujikan dapat dilihat pada Tabel 1.

Tabel 1. Hasil Identifikasi Golongan Metabolit Sekunder

\begin{tabular}{lllll}
\hline \multirow{2}{*}{ Golongan } & \multicolumn{4}{l}{ Ekstrak Kasar Metanol } \\
\cline { 2 - 5 } & Kokang & Merung & Bandotan & Daruju \\
\hline Alkaloid & + & + & + & - \\
Fenol & + & + & + & + \\
Flavanoid & - & - & - & - \\
Saponin & + & + & - & + \\
Tanin & + & + & + & - \\
Keterangan: $(+)=$ Teridentifikasi & $(-)=$ Tidak Teridentifikasi
\end{tabular}

Berdasarkan hasil identifikasi golongan metabolit sekunder pada ekstrak metanol dari beberapa tumbuhan yang diujikan, diketahui mengandung golongan alkaloid, fenol, flavonoid, saponin, dan tannin yang diduga memiliki aktivitas sebagai antioksidan. Senyawa golongan alkaloid didefinisikan sebagai substansi dasar yang memiliki satu atau lebih atom nitrogen yang bersifat basa dan tergabung dalam 
suatu sistem siklis, yaitu cincin heterosiklik. Senyawa berbasis nitrogen dari tumbuhan berpotensi menghambat proses oksidatif (Shahidi, 1997).

Dari keseluruhan ekstrak yang diujikan semuanya mengandung golongan senyawa fenol, dimana senyawa fenol merupakan kelas utama antioksidan yang berada dalam tumbuh-tumbuhan. Senyawa fenol dapat meredam radikal bebas dengan menyumbangkan elektronya melalui atom hidrogen gugus hidroksil, radikal bebas senyawa-senyawa fenol ini kemudian terstabilkan secara resonansi. dan karena itu tak reaktif dibandingkan dengan kebanyakan radikal bebas lain sehingga dapat berfungsi sebagai antioksidan yang efektif.

Senyawa tanin termasuk kedalam senyawa polifenol yang artinya senyawa yang memiliki bagian berupa fenolik. Beberapa tanin terbukti mempunyai aktivitas antioksidan dan menghambat pertumbuhan tumor (Robinson, 1995). Tanin yang telah diketahui berguna dalam farmasi yaitu katekin dan gallotanin ini mempunyai sifat antioksidan yang berperan dalam melawan radikal bebas yang sangat berbahaya bagi tubuh karena dapat menimbulkan berbagai penyakit salah satunya yaitu kanker.

\section{B. Aktivitas Antioksidan}

Aktivitas antioksidan adalah kemampuan ekstrak dalam menangkap radikal bebas. Untuk mengetahui besarnya persentase peredaman radikal bebas oleh ekstrak maka dilakukan uji aktivitas antioksidan dengan metode peredaman radikal DPPH dengan parameter nilai $\mathrm{IC}_{50}$. Prinsip metode ini adalah senyawa antioksidan dalam sampel akan bereaksi dengan radikal DPPH melalui mekanisme donasi atom hidrogen dan menyebabkan peluruhan warna DPPH dapat disajikan pada Tabel 2.

Tabel 2. Hasil Pengujian Aktivitas Antioksidan Ekstrak dan Fraksi

\begin{tabular}{lllll}
\hline \multirow{2}{*}{ Ekstrak/ Fraksi } & \multicolumn{4}{l}{ Aktivitas Antioksidan $\left(\mathbf{I C}_{\mathbf{5 0}}\right)$ dalam ppm } \\
\cline { 2 - 5 } & Kokang & Merung & Bandotan & Daruju \\
\hline Metanol & $\mathbf{4 9 , 9 1}$ & 113,60 & 259,18 & 78,03 \\
n-Butanol & 67,62 & 436,80 & $\mathbf{7 7 , 8 0}$ & 45,04 \\
Etil Asetat & 77,35 & 97,64 & 237,41 & $\mathbf{4 1 , 9 7}$ \\
n-Heksana & 88,32 & $\mathbf{6 9 , 0 2}$ & 86,34 & 174,22 \\
\hline
\end{tabular}

Berdasarkan Tabel 2 di atas dapat diketahui bahwa dari keempat jenis tumbuhan yang diujikan memiliki aktivitas antioksidan yang sangat baik, hal ini dapat dilihat dari besaran nilai $\mathrm{IC}_{50}$ dari masing masing ekstrak dan fraksi diperoleh kurang dari 200 ppm kecuali untuk fraksi methanol dan etil asetat dari tumbuhan bandotan yhang lebih dari 200 ppm.

Secara spesifik suatu senyawa dikatakan sebagai antioksidan jika nilai $\mathrm{IC}_{50}$ kurang dari 200 ppm nilai $\mathrm{IC}_{50}$ dan jika yang diperoleh berkisar antara 200 sampai 1000 ppm, maka zat tersebut kurang aktif namun masih berpotensi sebagai zat antioksidan Semakin rendah nilai $\mathrm{IC}_{50}$ mengindikasikan aktivitas yang tinggi. $\mathrm{IC}_{50}$ kurang dari $50 \mathrm{ppm}$ sangat aktif atau kuat, sedangkan jika nilai $\mathrm{IC}_{50}$ berkisar 50 ppm sampai 100 ppm cukup aktif atau sedang, 100 ppm sampai $200 \mathrm{ppm}$ sedikit aktif atau lemah. Jika nilai $\mathrm{IC}_{50}$ lebih dari 200 ppm tidak aktif (Molyneux, 2004). 
Berdasarkan hasil tersebut diatas terlihat bahwa ada hubungan antara golongan senyawa metabolit sekunder dengan aktivitas antioksidan dari sampel yang diujikan. senyawa fenolik telah diketahui memiliki berbagai efek biologis seperti aktivitas antioksidan melalui mekanisme sebagai pereduksi, penangkap radikal bebas, pengkhelat logam, peredam terbentuknya oksigen singlet serta pendonor elektron. Senyawa fenolik yaitu senyawa dengan suatu gugus hidroksi ($\mathrm{OH}$ ) yang terikat pada karbon cincin aromatik.

\section{KESIMPULAN}

Berdasarkan hasil penelitian dan pembahasan dapat ditarik kesimpulan sebagai berikut:

1. Golongan metabolit sekunder yang teridentifikasi dalam ektrak methanol dari tumbuhan kokang, merung, bandotan, dan daruju adalah golongan senyawa alkaloid, fenol, saponin dan tanin.

2. Aktivitas Antioksidan ektrak (Nilai $\mathrm{IC}_{50}$ ) dari tumbuhan kokang, merung bandotan, dan daruju berturut turut adalah 46,91 ppm, 69,02 ppm, 77,80 ppm, dan 41,97 ppm.

\section{DAFTAR PUSTAKA}

1. Al'amri, A.F., 2011. Aktivitas Antioksidan Akar Merung (Captosapelta Tomentosa Valeton K.) terhadap Radikal DPPH. Universitas Mulawarman, Samarinda.

2. Anggraini, N., 2012. Identifikasi Metabolit Sekunder dan Aktivitas
Antioksidan Daun Kokang

(Lepisanthes amoena). Universitas Mulawarman, Samarinda.

3. Critine, Y., 2011. Aktivitas Antioksidan Akar Daruju (Acanthus ilicifolius L.) dengan metode DPPH. Universitas Mulawarman, Samarinda.

4. Gill, M.I., Tomas, F.A.B., Pierce, B.H., and Kader, A.A. 2002. Antioxidant Capacities, Phenolic Compounds, Carotenoids, and Vitamin C Contents of Nectarine, Peach, and Plum Cultivars from California. J. Agric. Food Chem.

5. Molyneux, P. 2004. The Use of the Stable Free Radical Diphenyl Picrylhydrazyl (DPPH) for Estimating Antioxidan Activity. J. Songklanarkin J. Sci. Technol.

6. Reynertson, K.A. 2007. Phytochemical Analysis of Bioactive Constituens from Edible Myrtaceae Fruit, Dissertation. The city University of New York, New York.

7. Robinson, T. 1991. The Organik Constituen of Higher Plants. Diterjemahkan oleh K. Padmawinata. Kandungan Organik Tumbuhan Tingkat Tinggi. ITB, Bandung

8. Shahidi, F., Shukla, V. K. S. And Wanasundra, P. 1997. "Natural Antioxidants From Oilseeds". dalam F. Shahidi, editor. Natural Antioxidant Chemistry, Health Effects and Applications. Champaign Illnois: AOCS.

9. Simbolon, O., 2011. Identifikasi Metabolit Sekunder dan Aktivitas Antioksidan Daun Bandotan (Ageratum $\begin{array}{lll}\text { conyzoides } & L \text {.). Universitas }\end{array}$ Mulawarman, Samarinda. 